\title{
超軟弱地盤における高速道路盛土建設のための真空圧密改良
}

\author{
川井田実* 高 坂 敏 明** \\ 山田耕 一* 中熊 和 義 ${ }^{* * *}$

\section{Vacuum Consolidation for Construction of Expressway Embankment on Extremely Soft Ground}

by

\author{
Minoru Kawaida ${ }^{*}$, Toshiaki KosaKA ${ }^{* *}$, Koichi YamadA ${ }^{*}$ and Kazuyoshi NaKaKumA ${ }^{* * *}$
}

Maizuru-Wakasa expressway was constructed on the soft ground area consisting a thick layer of peat and soft clay. In trial embankment construction, a large lateral displacement and settlement due to embankment load were observed. Therefore, vacuum consolidation (air-water separation system type) was selected to apply to another trial area nearby the previous one to improve the ground for embankment construction. It was found that the vacuum pressure could maintain at high level even after a successive consolidation settlement up to about 10m, A significantly incremental soil strength after consolidation settlement were observed. The analysis of soil strength increment induced by vacuum consolidation compared to another case history was analyzed and described in this paper

Key words : Vacuum consolidation, Air-Water separation system, Soil improvement, Humic soil, Strength increase, Settlement acceleration

\section{1 緒言}

舞鶴若狭自動車道は, 中国道の吉川 JCT から分岐し, 福知山市・舞鶴市・小浜市等を経て敦賀 JCT で北陸道 に接続する，延長 $162 \mathrm{~km}$ の高速道路である。建設中区 間の小浜西〜敦賀 $50 \mathrm{~km}$ のうち, 福井県若狭町向笠地区 (Fig. 1) は，厚さ 50m の軟弱地盤が分布している.

若狭湾は山地が海岸に迫ったリアス式海岸であり，沈 降によって形成された三方五湖の周辺は, 出口が閉塞さ れた深いおぼれ谷が多数存在する。向笠地区も打ぼれ谷 のひとつで, Fig. 2 は地質縦断図である。腐植土と粘性 土が互層となっており，谷の中間部は粘性土が主体で腐 植土や砂質土を挟在する。両端部では腐植土が卓越し深 さ 30 〜 $40 \mathrm{~m}$ 程度まで厚く分布していることが特徴的で ある，粘性土・腐植土ともに，浅い層では $\mathrm{N}$ 值がほとん ど 0 で, 十分な安定・沈下対策が必要であることを示唆
している。深い層でも $\mathrm{N}$ 值は 10 未満であり，軟弱層と して考慮すべき対象となる。おぼれ谷を通過する道路延 長は約 $1.3 \mathrm{~km}$ で, 河川を跨ぐ $67 \mathrm{~m}$ の橋梁以外はすべて

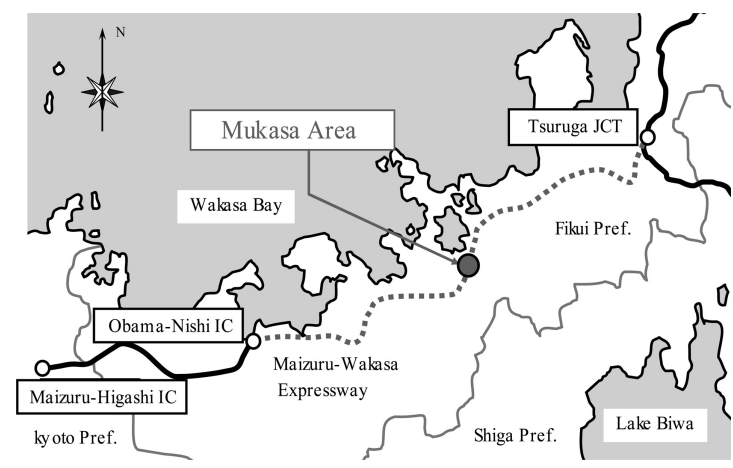

Fig. 1 Location Map.

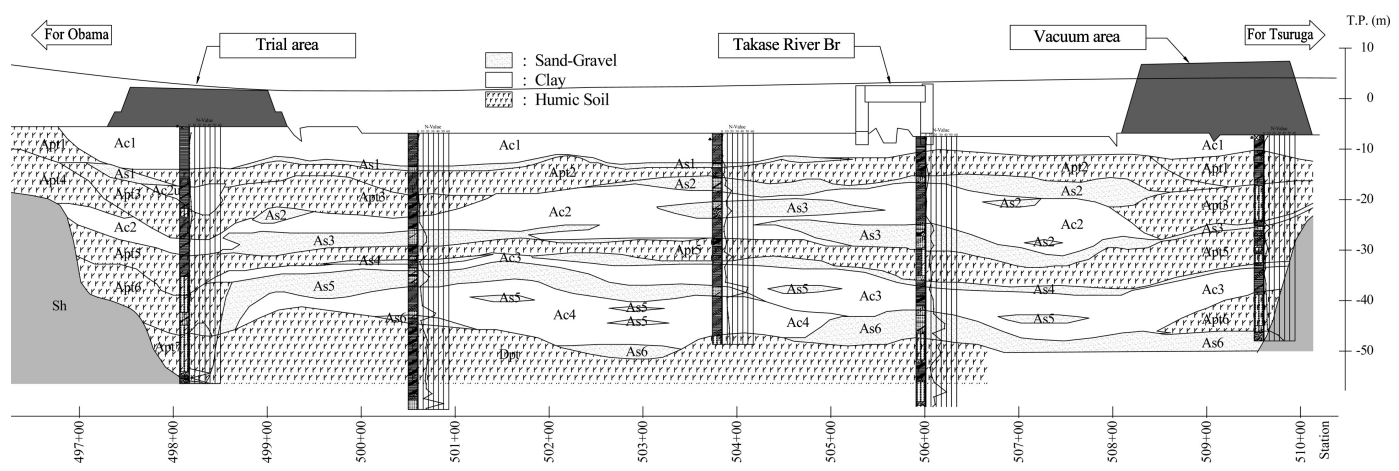

Fig. 2 Soil Profile.

\footnotetext{
$\dagger$ 原稿受理 平成 23 年 5 月 10 日 Received May 10, 2011 @ 2012 The Society of Materials Science, Japan

* 中日本高速道路㑣) ₹460-0003 名古屋市中区錦, Central Nippon Expressway Co., Ltd, Naka-ku, Nagoya, 460-0003

**（森)ダイヤコンサルタント（真空圧密技術協会） テ980-0811 仙台市青葉区一番町, Dia Consultants Co., Ltd., Aoba-ku, Sendai, 980-0811

*** 丸山工業(㑣）（真空圧密技術協会）７354-0043＼cjkstart埼玉県入間郡三芳町，Maruyama Industry Co., Ltd., Iruma-gun, Saitama, 354-0043
} 
盛土構造となっていて，計画高さは 7 ～11m である，こ の区間に扎て，Fig. 2 の左側（小浜方）で試験盛土を 行い，右側（敦賀方）では真空圧密工法で地盤改良し盛 土を施工している。本文は，ここで施工された真空圧密 工法について，地盤の挙動扎よびチェックボーリング結 果をまとめたものである.

\section{2 試験盛土による知見}

本工事に先立ち, 超軟弱地盤の挙動を把握し, 地盤改 良等の安定対策工の効果を確認するため試験盛土を行っ た。盛土の延長を $150 \mathrm{~m}$ とし, Fig. 3 の平面図に示すよ うに，小浜方からプラスチックボードドレーン改良区間 (PBD 併用区間)，サンドドレーン改良区間（SD 併用区 間），押え盛土区間を $50 \mathrm{~m}$ ずつとした。詳細は既報 ${ }^{1)}$ 譫り，ここでは，特徵的な地盤の挙動とそこから得られ た知見について述べる. Fig. 4 は，各区間の地表面沈下 の経時変化である。盛土は $3 \mathrm{~cm} /$ day で施工した。

沈下は最大で $11 \mathrm{~m}$ を超えて打り, 現在も $4 \mathrm{~cm} /$ 月程度 で進行中である．Fig. 5 は SD 併用区間の地中変位計の データである。深い腐植土層 (Apt 5, Apt 6) から横方向 に動いており，上部粘性土層とその下の腐植土層との境 界深度付近で約 $2 \mathrm{~m}$ の水平変位が発生した。 なお，地中 変位計の計測位置は，Fig. 6 の押え盛土のり尻と水路の 四に位置し，回転の中心付近となり, 鉛直変位が小さかっ たことから，深度の修正は行っていない．地表面は盛土 法尻から約 $50 \mathrm{~m}$ にわたって最大 $1.5 \mathrm{~m}$ 程度隆起し, 田の 耕作が不可能となった. Fig. 6 は左側法尻に設置した仮 設水路工の変状であり, 水路は外へ動きつつ底部が押し

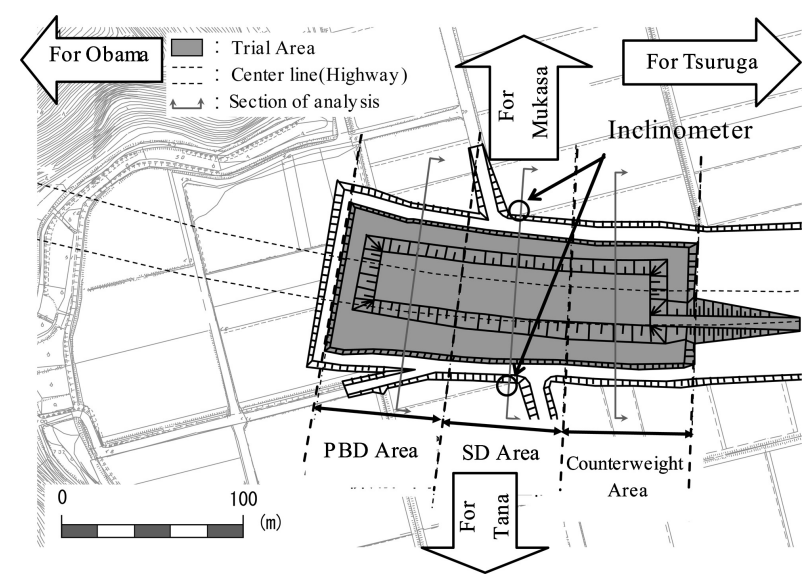

Fig. 3 Plane of Trial Area.

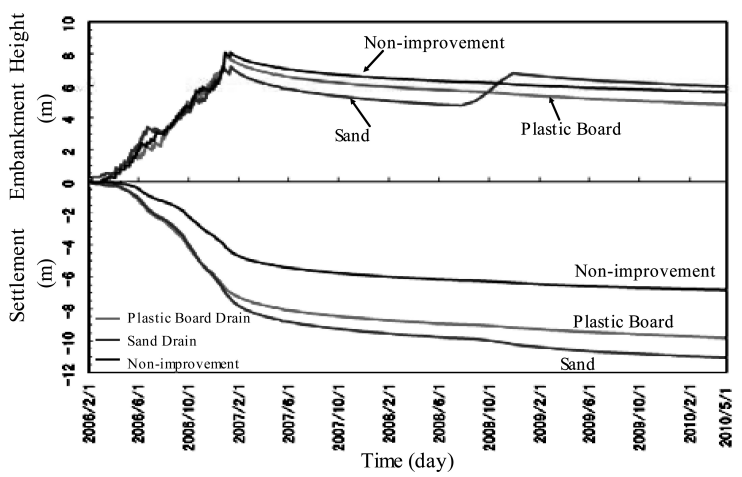

Fig. 4 Time course of Settlement at Trial Area.

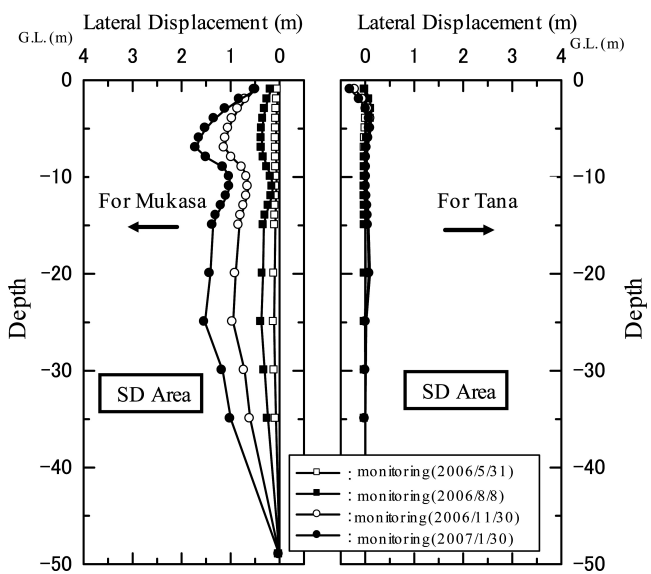

Fig. 5 Lateral Displacement of SD Area.

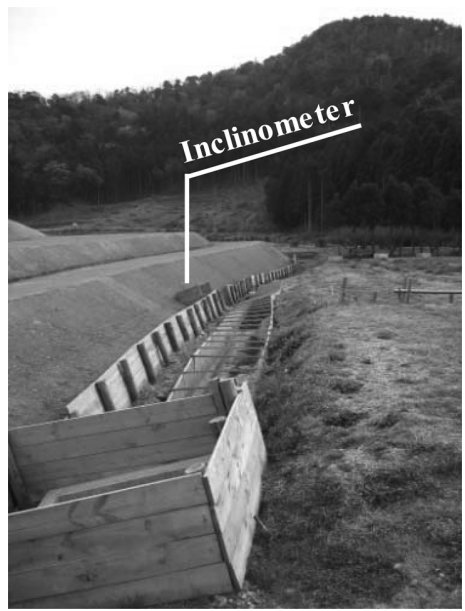

Fig. 6 Deformation of Waterway by Lateral Flow.

上げられるように変形し，傾斜してしまった。しかし， 盛土がすべり破壊に至ることはなかった。

試験盛土の結果，以下の知見を得た.

（1）すべり破壊には至らなかったものの，地中変位や 周辺構造物の変状から, 非常に不安定な状態であると考 えられることから, 盛土速度をさらに遅くする必要がある.

（2）周囲の耕作地を広範囲に変形させることは，地元 に多大な迷惑となり休作補償等の経費もかさむ.

(3) 深層の腐植土層でも大きな側方変形および沈下が 発生していることから, バーチカルドレーンの打設深さ を延伸し，深層部の圧密を促進したほうがよい.

\section{3 真空圧密の採用}

試験盛土による知見から，おぼれ谷の敦賀方の深い腐 植土層地盤（Fig. 2 の右側の盛土）に打ける対策を検討 した。当初採用したのは，(1) プラスチックボードドレー ンを深さ $34 \mathrm{~m}$ まで延伸，(2) 試験的に鋼矢板（深さ $10 \mathrm{~m}$ ) を一部区間に設置，(3) 盛土速度を盛土高さ（すなわち， 沈下分も含めると盛土厚さ $5 \mathrm{~cm} /$ day 相当）に基づいて ではなく, 盛土厚さに基づいて $3 \mathrm{~cm} /$ day でコントロール する，といったものである。(1)および(2)の施工を完了し たのち，再度後続工事の工程を検討したところ，盛土完 了後に着手するトンネルおよびカルバートの工程に余裕 がないことが判明したので，盛土を速く施工するための 対策として真空圧密を採用した。真空圧密は NEXCO で 
実績のある，徹底した気水分離 ${ }^{2)}$ により高真空が期待で きるシート式高真空圧密工法 ${ }^{3)}$ を採用した.

すでにプラスチックボードドレーンが $1.2 \mathrm{~m}$ 間隔の正 方形配置で施工された地盤に，真空圧密用のプラスチッ クボードドレーンを同間隔で深さ $20 \mathrm{~m}$ まで施工した。 な お，既設のプラスチックドレーンは真空圧密のシステム には連結されていない，施工面積が約 $9000 \mathrm{~m}^{2}$ あり，真 空ポンプは 3 台設置した。計画盛土高さは, サーチャー ジ分も含めて $14 \mathrm{~m}$ あり, サーチャージ効果をさらに有効 なものとするため, 真空圧をかけながら盛土を施工した.

\section{4 地 盤 $の$ 挙 動}

Fig. 7 は, 動態観測計器の配置, 地表面沈下 · 真空 压・排水量 - 層別沈下 - 過剰間隙水圧 - 地中変位の経時 変化を示したものである.これらの罒から以下のことが いえる.

(1) 真空圧はコンスタントに $80 \mathrm{kN} / \mathrm{m}^{2}$ 程度であり， 有効に作用している。盛土開始前に約 $1 \mathrm{~m}$ 沈下していた.

（2）排水量はポンプ稼動初期には $400 \mathrm{~m}^{3} / \mathrm{day}$ を超え ていたが，圧密がすすむに従い徐々に $200 \mathrm{~m}^{3} /$ day 程度に 減少している。

（3）地表面沈下は 2009 年 12 月の真空ポンプ停止時 点で最大 $10.6 \mathrm{~m}$ となった (Fig. 7 参照)．周辺地盤の鉛 直変位は非常に小さい.

(4) 層別の圧縮量は, 深度 $9.8 \mathrm{~m}$ までの Ac 1 と Apt 1 が大きく, 沈下前の層厚がほほ約半分になる $51 \%$ のひず みとなる。次いでApt 3 層が約 $38 \%$ のひずみが発生して いる.

（5）盛土速度は全体平均では $3 \mathrm{~cm} /$ day と通常の緩速 施工と変わらないが, 盛土終盤では $8 \mathrm{~cm} /$ day 程度となっ ており，盛土厚さ $3 \mathrm{~cm} /$ day で施工したと仮定した場合に
比べて，1 年強の工程短縮となった.

(6) 途中で計測不能となったものの, 真空圧密のプラ スチックボードドレーン深さ (20m) よりも深い G.L.-30m の間隙水圧計も負の值を示し，真空圧が影響を及ぼして いる.

（7）当地区のように沈下量が非常に大きく，間隙水圧 計自体の沈下も無視できないオーダーとなる，そのため， 間隙水圧計と同深度に層別沈下計を設置し，Fig. 8 の間 隙水圧の軌跡困として整理した。これによると, 盛土の安 定性に大きく影響を与える深度 $7 \mathrm{~m}$ の間隙水圧は, 盛土荷 重の増加に伴い増加傾向を示すものの, 最大で $20 \mathrm{kN} / \mathrm{m}^{2}$ の比較的小さい值であった。さらに，盛土完了後は，減 圧傾向を示し，真空ポンプ停止直前には， $-54 \mathrm{kN} / \mathrm{m}^{2}$ ま で低下している．下部の $17 \mathrm{~m}$ に設置された間隙水位圧計 においては，真空ポンプ稼働後早い時期から $-60 \mathrm{kN} / \mathrm{m}^{2}$ の圧力を示し，真空ポンプ停止直前には， $-48 \mathrm{kN} / \mathrm{m}^{2}$ を 記録している．真空ポンプ停止後は，水圧が上昇するも のの概ね静水圧付近にプロットされる.

（8）地中変位は，盛土施工前で真空圧のみ作用してい るときには盛土側に $20 \mathrm{~cm}$ 程度引き込んでいた。盛土の 施工とともに外側に変位しはじめたが，最大でも $1 \mathrm{~m}$ 程 度となっている．地中変位が深さ $10 \mathrm{~m}$ 付近で大きく出て いるのは，矢板の先端深さと一致している。

（9）深い腐植土である Apt 5 層は，層圧縮量が $1 \mathrm{~m}$ 程 度発生しているが，地中変位が小さい。試験盛土におけ る深部の腐植土層 (Apt 5, Apt 6) の地中変位がともに大 きかったこととは異なった現象である。これは，プラス チックボードドレーンを Apt 5 層に延伸した効果である と考えられる.

（10） Fig. 9 に真空圧密改良範囲の層別沈下量の経時

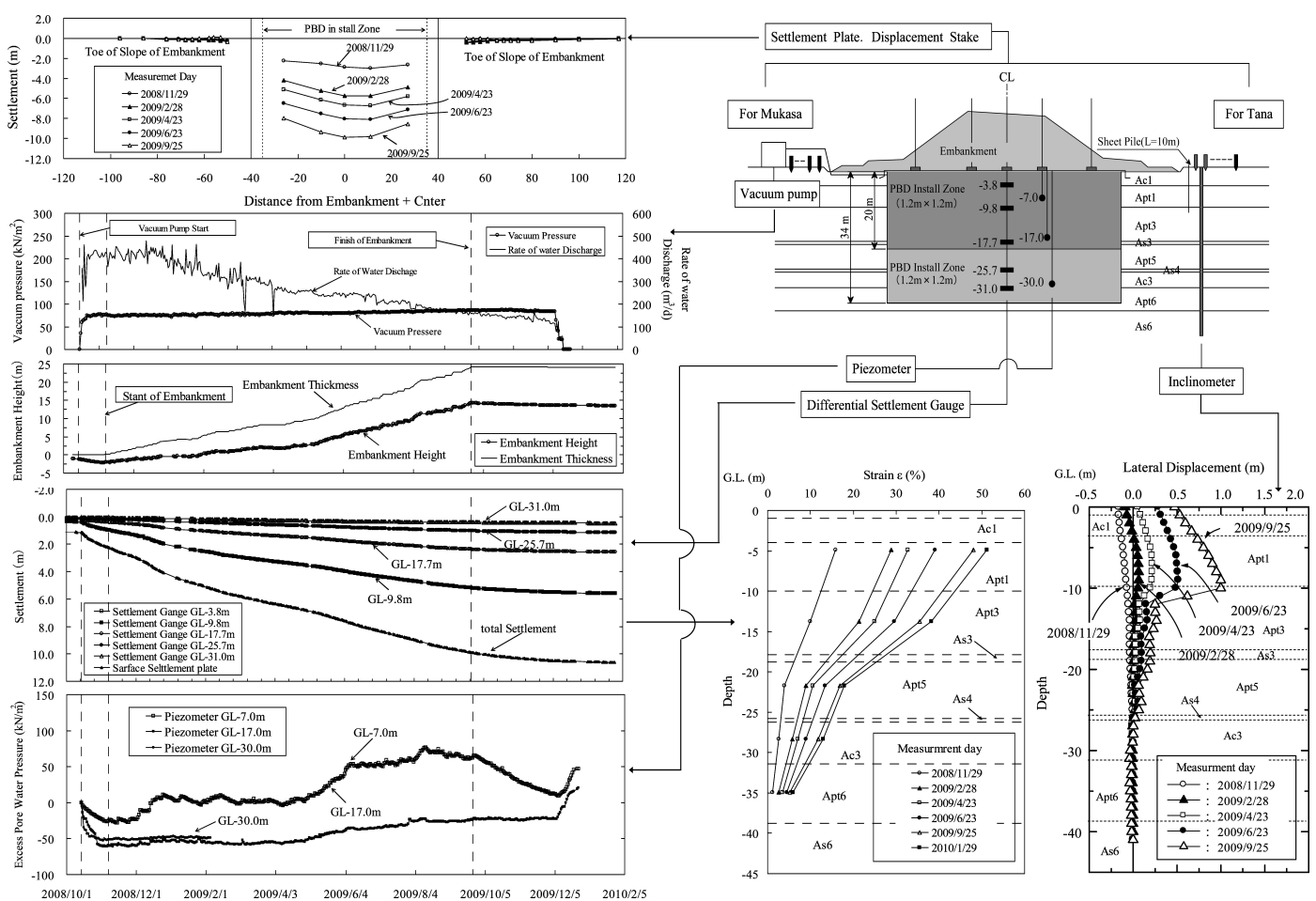

Fig. 7 Monitoring Date of Vacuum Consolidation Area. 


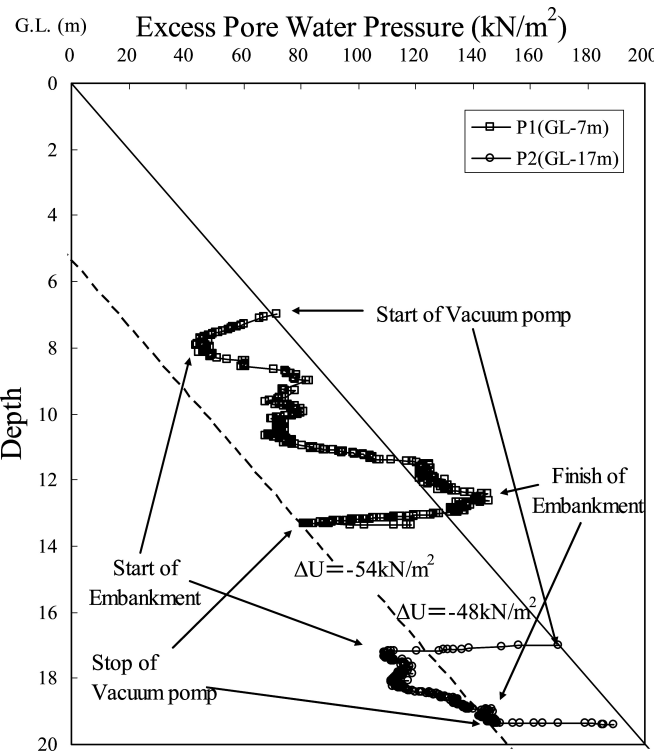

Fig. 8 Transformation of Pore Water Pressure.

変化を示す．罒中の実線は，盛土の施工実績に併せて計 算したバロン解に基づく圧密沈下量である。なお本地区 は，深度方向でドレーンのピッチが異なることから，真 空圧密用のドレーンが貫通している深度 $17.7 \mathrm{~m}$ までの層 別沈下計のデータで整理している.一般に断面積が小さい プラスチックボードドレーンを採用した場合，排水抵抗に 起因したウエルレジスタンスの影響により，沈下が遅れる ことが知られているが，本事例の場合は，林ら ${ }^{4)}$ の報告同 様，ウエルレジスタンスを考慮しないケースで沈下曲線が 近似している。これは, 真空圧密工法ではドレーン内部 が減圧され，その動水勾配により軟弱層の水を強制的に 脱水するというメカニズムに起因するものと考えられる.
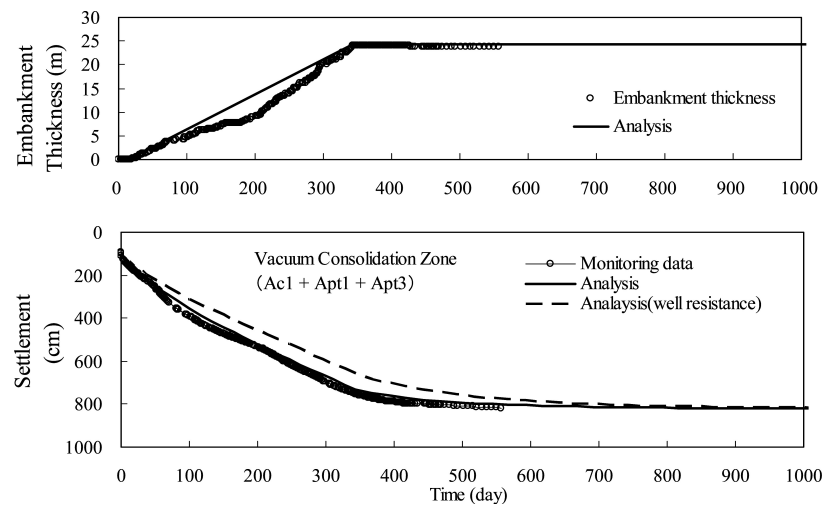

Fig. 9 Veroclty of Settlement Conparison between Measured and Analysis.

\section{5 チェックボーリング}

盛土が立ち上り真空ポンプを停止させた後, 2010 年 4 〜 6 月にかけてチェックボーリングを行い，地盤物性の変 化を調べた

チェックボーリングは, Fig. 10 に示すように, 横断方 向の 7 箇所で実施した。 その結果，当初，気密シートの 内外で大きな沈下差が生じているのではないかというこ とが懸念されたが，全体に滑らかな沈下形状を呈してい た，当地区では，盛土下部に補強材が敷設されており， この補強材による盛土の拘束効果が影響している可能性 も考えられる，側道部では，調査時点で周辺水田部と同 程度の地盤高であるにも関わらす, $5 \mathrm{~m}$ 近い沈下が生じ ていることが確認された。 また，当初は水平な地盤構成 を想定していたが，右側押え盛土のり尻では基盤の高ま りが確認され，路線左側は，丘陵が近接しているため, 軟弱層は，盛土を中心に凹状の形状に堆積している可能 性が高いことが確認された。

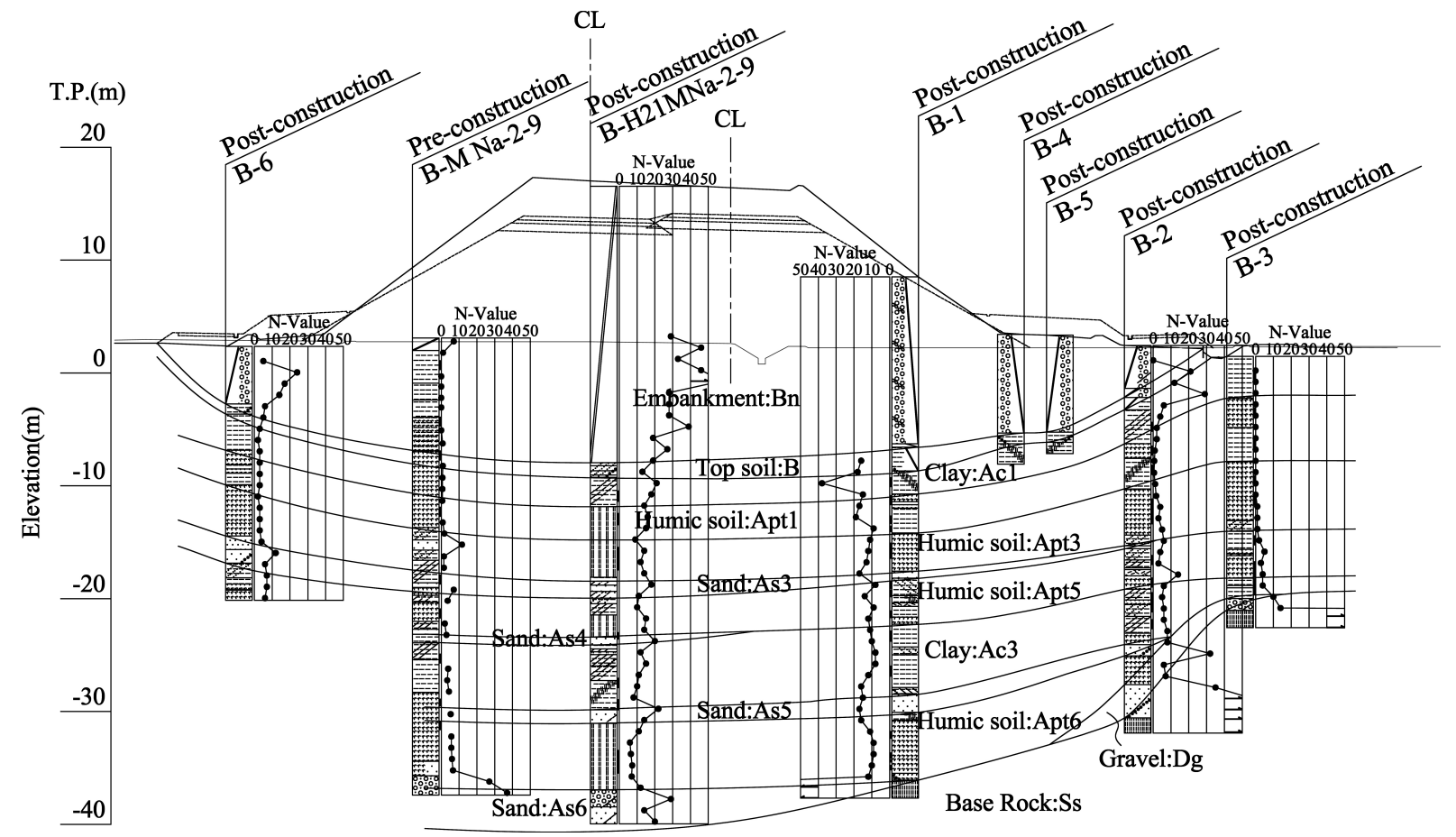

Fig. 10 Cross Section of Post-Construction. 
Fig. 11 に施工前後の $\mathrm{N}$ 值の深度分布を示す。な打， 施工前後では沈下により試験を実施した標高が異なるた め，層別沈下計のデータに基づき層厚を比例分布し，沈 下前の深度に補正している。これ以降の深度分布図も同 様の補正を行っている。真空圧密改良範囲の深度 $-20 \mathrm{~m}$ 付近までの施工前の $\mathrm{N}$ 值は，概ね $0 \sim 2$ であったのに 対し, 真空ポンプ停止後は, $10 \sim 20$ まで増加している. Fig. 12 に自然含水比の深度分布を示す。真空圧密改良 範囲では, 自然含水比の減少が著しく, 施工前は最大 $400 \%$ であったが，改良後は最大 $200 \%$ 程度となっている。 標高-20m 以深では, 自然含水比の低下は明瞭ではない.

\section{6 非排水せん断強さ}

Fig. 13 に真空圧密工法の施工前後の非排水せん断強 さの深度分布を示す．同図中に線分で表示されているの は, 次式で求めた強度である。 な打, 真空圧密による減 圧は，Fig. 9 に示した実測值を用いている.

ここで, $S_{u}=\left(p_{0}+\Delta p+p_{v}\right) \times m$

$S_{u}$ ： 非排水せん断強さ $\left(\mathrm{kN} / \mathrm{m}^{2}\right)$

$p_{0}$ : 初期有効応力 $\left(\mathrm{kN} / \mathrm{m}^{2}\right)$

$\Delta p$ ：盛土による増加応力 $\left(\mathrm{kN} / \mathrm{m}^{2}\right)$

(施工実績より盛土材 $\gamma_{t}=21.5\left(\mathrm{kN} / \mathrm{m}^{3}\right)$ 地下 水位以下は $\gamma^{\prime}=13.1\left(\mathrm{kN} / \mathrm{m}^{3}\right)$ とし, ブーシネス ク式で計算)

$p_{v}$ ：真空圧密による減压 $\left(\mathrm{kN} / \mathrm{m}^{2}\right)$ As 3 層より 上部 $53.6\left(\mathrm{kN} / \mathrm{m}^{2}\right)$, 下部 $48.2\left(\mathrm{kN} / \mathrm{m}^{2}\right)$

$m$ ： 強度増加率（設計值 Ac 1 , Ac $3 m=0.35$, Apt 1 , Apt $3 m=0.40$, Apt $6 m=0.45$, Apt $5 m=0.50$ )

同図によると, 真空圧密改良範囲では, ばらつきはあ るものの，実測の非排水せん断強さは，計算值を概ね満 足する結果が得られている。プラスチックボードドレー ン改良範囲では，圧密度を $100 \%$ として算定しているた め, 実測值が計算値より小さい範囲にプロットされるが, 真空圧密改良範囲の強度增加とは明らかに異なることが 読み取れる。未改良範囲では，施工前後で同程度の値を 示し，強度増加が小さい結果となっている。これについ ては, 圧密が遅れていることに起因するのか, 調査結果 で述べた凹状の基盤の影響に起因するものか，現段階で は判断ができない

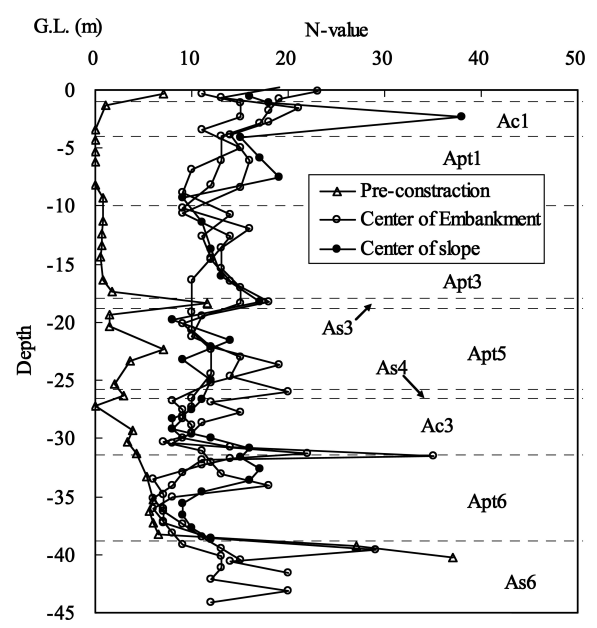

Fig. 11 Distribution on N-value.

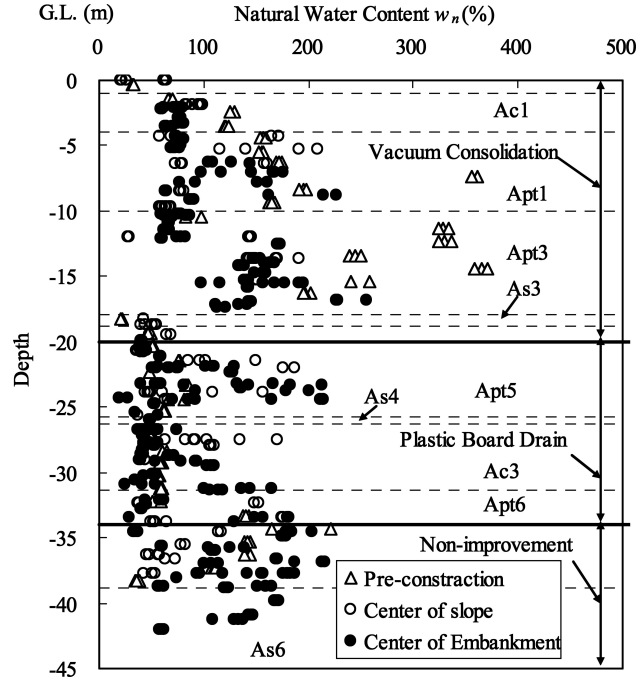

Fig. 12 Distribution Natural Water Content.

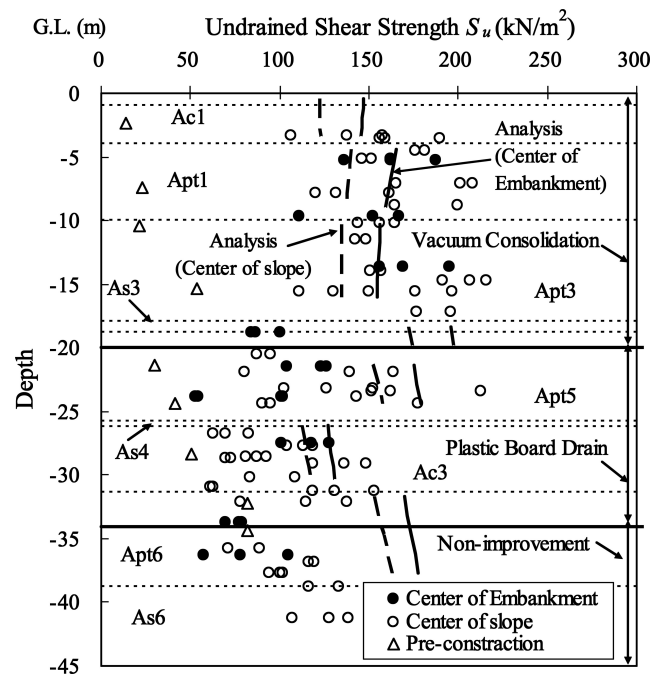

Fig. 13 Distribution of Undrained Shear Strength.

\section{7 圧密降伏応力}

Fig. 14 に圧密降伏応力の深度分布を示す．同図に実 線で表示しているのは, 非排水せん断強さと同様に, 次 式で算定した有効応力である。

$$
p=p_{0}+\Delta p+p_{v}
$$

ここで, $p_{v}$ : 真空ポンプ停止直前の有効応力 $\left(\mathrm{kN} / \mathrm{m}^{2}\right)$ 同図によると，非排水せん断強さの深度分布の傾向と 異なり，圧密降伏応力は，明らかに計算以上に增加して いる。また，プラスチックボードドレーン改良範囲にお いても計算值を上回る結果が得られている。

ただし，盛土中央で実施した未改良範囲の試験結果で は，明瞭な圧密降伏応力の変化は確認されていない。

\section{8 強度增加率}

施工前後の圧密降伏応力と非排水せん断強さの関係を Fig. 15 に示す。同図によると粘性土 Ac1については， NEXCO 設計要領の目安值である粘性土の強度増加率 $m=0.30$ を中心にプロットされる，腐植土 Apt1，Apt3， Apt5 は，ばらつきが大きいものの，強熱減量が $\mathrm{Li}=30 \%$ 以上のデータを中心に見ると各層とも強度増加率は， $m=$ 0.40 程度の有機物を含む土層の值を示す。 


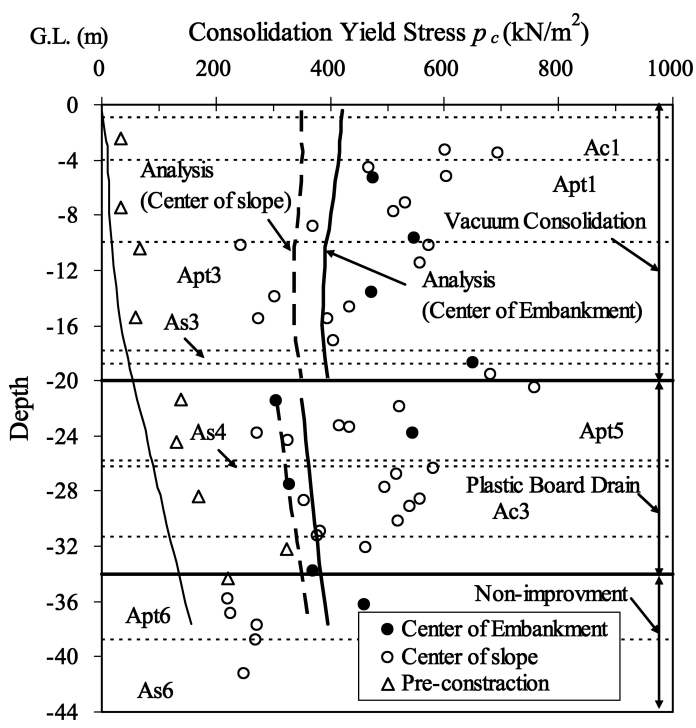

Fig. 14 Distribution of Consolidation Yield Stress.

ここで, 過去の真空圧密工法で改良された地盤の強度 増加に関する論文では, 真空圧密工法の強度増加率が他 の工法より大きい值を示す事例 ${ }^{3}$ も報告されている。 た だし，今回の事例では，その傾向は認められていない． 確かに真空圧密工法単独の場合は, 等方的に応力が作用 するが，盛土荷重は，側方がある程度拘束された状態で 圧密が進行する。ここで, 理解しやすいように強度増加 率の変化が $K_{0}$ 值の影響のみを受けると仮定し, 強度増 加率の変化を次式で表現してみる.

$$
m_{c v c}=\frac{m_{\text {aniso }} \cdot\left(p_{0}+\Delta p\right)+m_{\text {iso }} \cdot p_{v}}{p_{0}+\Delta p+p_{v}}
$$

強度増加率の変化 $=m_{v c} / m_{\text {aniso }}$ ここで,

$m_{c v c}$ ：真空圧密工法による強度増加率

$m_{\text {aniso }}: K_{0}$ 圧密による強度増加率 $(0.4$ とする $)$

$m_{\text {iso }}$ ：等方圧密による強度増加率

$\left(\mathrm{K}_{0}=0.5\right.$ とし $m_{\text {aniso }} \times 3 \sigma_{1} /\left(2 \mathrm{~K}_{0} \cdot \sigma_{1}+\sigma_{1}\right)=0.6$ と仮定した)
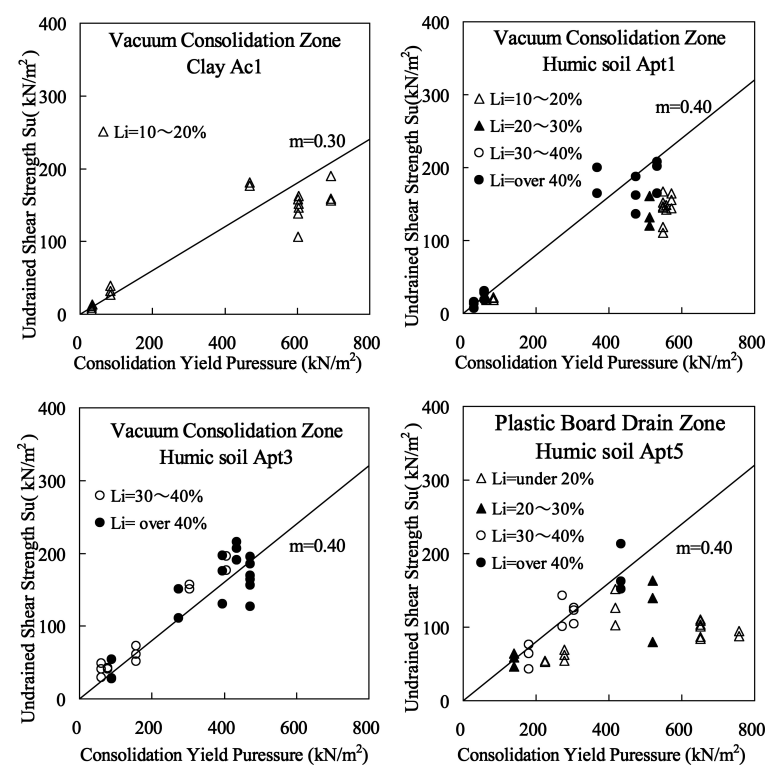

Fig. 15 Rate of Strength Increase.

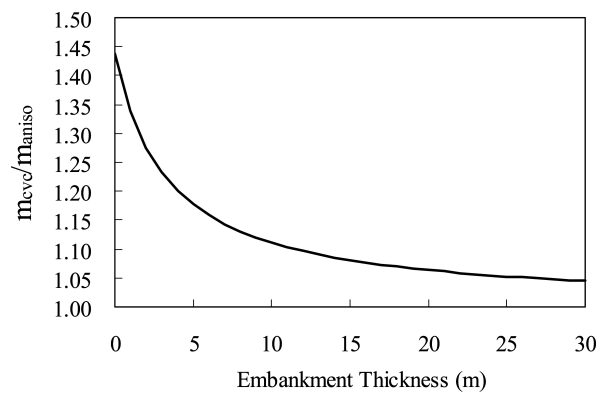

Fig. 16 Proportional change of rate of Strength Increase.

$$
p_{0} \quad \text { : 初期有効応力 }\left(10\left(\mathrm{kN} / \mathrm{m}^{2}\right) \text { と仮定 }\right)
$$

盛土の単位体積重量を施工実績の $\gamma_{t}=23.5\left(\mathrm{kN} / \mathrm{m}^{3}\right)$ として計算した結果を Fig. 16 に示す。同図によると， 盛土厚が少ない場合には一般的な強度増加率より大きく なる傾向を示すが，盛土荷重が大きくなるにつれ，その 傾向は小さくなり, 当該地区の施工盛土厚 $24 \mathrm{~m}$ では通常 の強度増加率の 1.054 倍程度にとどまる。

$$
9 \text { 結 言 }
$$

真空圧密の採用によって, 大幅な工程短縮と周辺地盤 への側方変形抑制が実現できた。ここに至るには試験盛 土の功績が大きく, 盛土速度の見直しや側方変形（田面 隆起，地中変位）抑制対策の重要性を認識させてくれた といえる. 真空圧の評価については課題が残されている が，試験盛土と同程度の超軟弱地盤で，試験盛土よりも 高い盛土を, 短期間で安定に, かつ周辺への影響を小さ く施工できたのは, 真空圧密による圧密促進効果にほか ならない.

深い層では圧密の終了には至らなかったと考察される が，今後もこの箇所での動態観測を継続し，二次圧密を 含めた残留沈下を把握して, 真空圧密の効果をさらに分 析していきたい，さらには，道路の供用後も観測を継続 して行い，当軟弱地盤区間でのライフサイクルコストの 検証を行っていく所存である.

\section{参 考 文 献}

1) M. Kawaida, J. Nobuta, M. Hirata and K. Yamada, "Construction of expressway on thick humic layer -countermeasures for soft ground of Maizuruwakasa expressway-", 54th geotechnology symposium, pp.563-570 (2009) Japanese Geotechnical Society.

2 ) G.Imai,"For the further development of "vacuum-induced consolidation method" -present understandings of its principle and applications-”, Journal of geotechnical engineering, No.898/VI, pp.1-16 (2005) Japan society of civil engineers.

3 ) Vacuum Consolidation Technology Association, "Conpact vacuum consolidation technical document”, p.8 (2004).

4) H. Hayashi, A. Ebisawa, S. Akimoto, T. Kousaka and M. Igarashi, "Application of the vacuum consolidation method in the Kushiro new road of National highway Route 38", Geotechnical Forum Tohoku 2001, pp.98-105 (2001) Japanese Geotechnical Society. 